\title{
Pendekatan Etnomatematika: Bagaimana Pengembangan Media Komik Dalam Pemecahan Masalah Pada Pembelajaran Matematika SD?
}

\author{
Lia Fahrunnisa, Adi Apriadi Adiansha*, Ady Irawan, Amrin, Zulharman \\ STKIP Taman Siswa Bima, Bima, Indonesia \\ *Coresponding Author: adiapriadiadiansyah@gmail.com \\ Dikirim: 11-06-2021 ; Direvisi: 17-06-2021 ; Diterima: 20-06-2021
}

\begin{abstract}
Abstrak: Penelitian ini bertujuan untuk mengembangkan dan mengetahui kelayakan dari media komik dalam pemecahan masalah pembelajaran SD melalui pendekatan etnomatematika pada materi bilangan serta untuk mengetahui respon Siswa SD terhadap kelayakan komik sebagai media pembelajaran. Penelitian pengembangan ini dilakukan dengan menggunakan model 4-D yang terdiri dari define, design, develop, dan disseminate. Pada tahap define dilakukan analisis potensi masalah dan pengumpulan data, tahap design dilakukan penyusunan perangkat penelitian, pemilihan media, pemilihan format, dan desain awal media komik matematika, tahap develop dilakukan penilaian oleh ahli, revisi I, uji coba terbatas, dan revisi II, kemudian tahap disseminate dilakukan penyebarluasan. Penelitian ini dilaksanakan di SDN 5 Sila dengan subjek penelitian sebanyak 20 siswa. Hasil penelitian menunjukkan bahwa penilaian ahli materi, guru matematika, dan ahli media rata-rata skor 4,12 termasuk kategori layak. Hasil respon Siswa rata-rata skornya 4,24 dengan kategori layak. Hasil uji pengembangan untuk mengukur peningkatan pemahaman Siswa dilakukan dengan menggunakan pre-test dan post-test diperoleh persentase peningkatan sebesar 14,5\% yang menujukkan peningkatan pemahaman Siswa cukup baik.
\end{abstract}

Kata Kunci: Pemecahan Masalah, Media Komik, Etnomatematika

\begin{abstract}
This study aims to develop and determine the feasibility of comics media in solving elementary school learning problems through an ethnomathematical approach to number material and to determine the response of elementary school students to the feasibility of comics as learning media. This development research was conducted using a 4D model consisting of define, design, develop, and disseminate. In the define stage, analysis of potential problems and data collection is carried out, the design stage is carried out by compiling research tools, media selection, format selection, and initial design of mathematical comic media, the develop stage is carried out by an expert assessment, revision I, limited trial, and revision II, then the disseminate stage is carried out by dissemination. This research was conducted at SDN 5 Sila with 20 students as research subjects. The results showed that the assessment of material experts, mathematics teachers, and media experts had an average score of 4.12 including the appropriate category. The results of the student's response have an average score of 4.24 with a decent category. The results of the development test to measure the increase in students' understanding were carried out using the pre-test and post-test, the percentage increase was $14.5 \%$ which showed the increase in students' understanding was quite good.
\end{abstract}

Keywords : Problem Solving, Comic Media, Ethnomathematics, Mathematics Learning

\section{PENDAHULUAN}

Fakta yang terjadi pada siswa sekolah dasar di Kecamatan Bolo Kabupaten Bima yaitu terjadinya permasalahan klasik yang sering dijumpai dalam mata pelajaran matematika sehingga munculnya stigma negatif pada Siswa (Gumanti, Supriadin, \& Suherman, 2018). Tidak jarang pelajaran matematika dijadikan 'momok' dan dipandang sebelah mata oleh Siswa. Bahkan, banyak dari mereka yang 
menilai matematika sebagai mata pelajaran yang sulit bahkan membosankan (Tarusu, Zulela, \& Adiansha, 2020; Adiansha \& Khatimah,2020)

Pernyataan tersebut sejalan dengan hasil wawancara yang dilakukan oleh penelitian dengan guru mata pelajaran. Wawancara dilakukan pada tanggal 15 maret 2021 di ruang guru. Hasil wawancara dengan guru matematika tersebut menunjukkan bahwa ada beberapa faktor yang menyebabkan Siswa menganggap bahwa mata pelajaran matematika sebagai pelajaran yang sulit dan membosankan. Pertama, kemampuan Siswa yang rendah sejak SD khususnya pada operasi dasar. Kedua, kurangnya minat dan motivasi dari dalam diri Siswa untuk belajar. Ketiga, rasa takut dalam diri Siswa auntuk mengajukan pertanyaan jika tidak mengerti. Keempat, kesulitan mengerjakan soal-soal latihan karena kurang memahami materi pelajaran yang diajarkan. Kelima, kurangnya minat Siswa untuk mengulang pembelajaran. Keenam, tidak ada media yang digunakan untuk membangun pemahaman konsep Siswa, karena guru jarang menggunakan media pembelajaran untuk menunjang kegiatan belajar mengajar. Guru lebih nyaman melakukan kegiatan belajar dan mengajar secara konvensional.Lastaria \& Istiqlaliyah, (2019)Fauzi et al., (2020)

Guru professional dituntut mampu memilih dan menggunakan berbagai media pembelajaran yang ada disekitarnya. Dalam proses pembelajaran guru mampu menggunakan banyak sumber dan media pembelajaran, seperti buku teks, modul, film, video, televisi, slide, web, atau komik. Rachmat \& Winata, (2019)

Dari hasil wawancara diperoleh informasi bahwa guru belum pernah menggunakan media pembelajaran berupa komik matematika. Pembelajaran dengan menggunakan media komik telah banyak diterapkan oleh beberapa negara maju seperti Jepang. Beberapa buku pelajaran sekolah di Jepang ada yang di desain dalam format komik. Bahkan untuk mendukung keberadaan kartun dan komik di negara Jepang telah didirikan fakultas khusus untuk memperdalam bidang kartun dan komik di Universitas Seika, Kyoto. (Ahmat \& Sukartiningsih, 2013)

Pengajaran matematika pun seharusnya disesuaikan dengan budaya Siswa di SDN 5 SILA. Kesulitan Siswa memahami matematika yang diperoleh di bangku sekolah serta kesulitan Siswa menghubungkannya dengan kehidupan nyata menjadikan faktor utama pentingnya pengintegrasian pembelajaran berbasis budaya dalam pembelajaran. Untuk itu diperlukan suatu pendekatan yang dapat menghubungkan antara matematika di luar sekolah dengan matematika di dalam sekolah. Salah satunya dengan memanfaatkan pendekatan etnomatematika.Wujud kebudayaan yang berkaitan dengan aktivitas manusia merupakan fenomena matematika yang terdiri dari enam kegiatan mendasar. Aktivitas-aktivitas tersebut dapat ditentukan pada sejumlah kelompok budaya yaitu: menghitung- membilang, menentukan lokasi, mengukur, mendesain, bermain dan menjelaskan. (Tusriyanto, 2020)(Rudyanto, 2019)

Berdasarkan uraian masalah diatas maka akan dilaksanakan penelitian dengan judul "Bagaimana Pengembangan Media Komik Dalam Pemecahan Masalah Pada Pembelajaran Matematika SD ?".

\section{METODE PENELITIAN}

Lokasi peneilitian ini dilaksanakan di SDN 5 SILA. Instrument yang digunakan dalam penelitian ini adalah pedoman wawancara, lembar pre-test $\&$ posttest, serta angket kelayakan produk. 
Jenis penelitian yang digunakan dalam penelitian ini adalah penelitian pengembangan (Research and Development). Suatu proses atau langkah-langkah untuk mengembangkan suatu produk atau menyempurnakan produk yang telah ada yang dapat dipertanggung jawabkan. Model dari penelitian ini menggunakan model 4-D yang terdiri dari tahap pendefinisian (define), perancangan (design), pengembangan (develop), dan tahap penyebaran (disseminate).

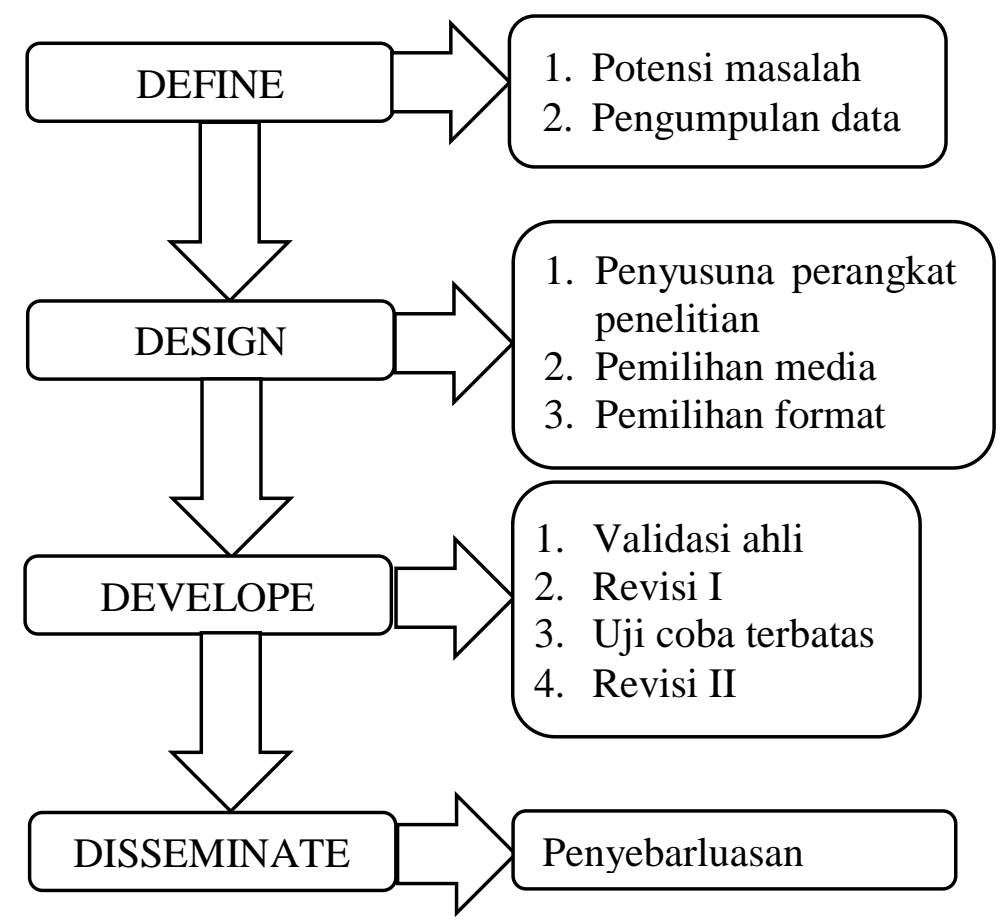

Gambar 1. Prosedur Pengembangan Model 4-D

Analisis data kuantitatif dari hasil angket penilaian Media Komik Matematika dengan Pendekatan Etnomatematika oleh ahli materi, ahli media, guru matematika dan Siswa diperoleh data kuantitatif. Konversi data kuantitatif ke kualitatif dapat dilakukan dengan acuan pada Tabel 1.

Tabel 1. Konversi Data Kuantitatif ke Data Kualitatif Skala Lima

\begin{tabular}{lc}
\hline \multicolumn{1}{c}{ Interval } & Kategori \\
\hline$X>X i+1,80 S b i$ & Sangat Layak \\
\hline$X i+0,60 S b i<X \leq X i+1,80 S b i$ & Layak \\
\hline$X i-0,60 S b i<X \leq X i+0,60 S b i$ & Cukup Layak \\
\hline$X i-1,80 S b i<X \leq X i-0,60 S b i$ & Kurang Layak \\
\hline$X \leq X i-1,80 S b i$ & Sangat Kurang Layak \\
\hline
\end{tabular}

\section{HASIL PENELITIAN}

Dalam pengembangan media komik matematika ini desain pengembangan yang dilakukan berdasarkan tahapan langkah-langkah pengembangan yang dimodifikasi oleh Sugiyono, yaitu: define, design, develop, dan disseminate.

\section{Define}


Tahap pertama adalah define (pendefinsian) yang merupakan tahap awal atau persiapan untuk pengembangan. Tahap ini bertujuan untuk menetapkan dan mendefinisikan syarta-syarat pembelajaran. Tahap ini meliputi dua langkah pokok yaitu pengumpulan potensi dan masalah. Pengambilan data untuk menguraikan potensi dan masalah dapat diperoleh dari hasil observasi, hasil wawancara dengan guru matematika dan hasil penelitian-penelitian sebelumnya. Observasi ini dilakukan dengan cara mengamati proses pembelajaran seerti melihat perilaku peserta didik, metode dan media pembelajaran yang digunakan oleh guru. Dari hasil wawancara diperoleh informasi bahwa guru jarang sekali menggunakan media pembelajaran. Guru juga belum pernah menggunakna media pembelajaran berupa komik matematika

\section{Design}

Tahap kedua adalah design (perancangan) yang tahap pembuatan media. Tahap ini meliputi penyusunan perangkat penelitian, pemilihan media pembelajaran, pemilihan format komik matematika, dan pembuatan desain awal komik matematika serta mengumpulkan bahan-bahan yang diperlukan dalam proses pengembangan. Berkaitan dengan itu materi yang dipilih adalah materi bilangan untuk kelas V.

\section{Develop}

Tahap ketiga adalah develop (pengembangan) yang merupakan tahap penilaian oleh ahli materi, ahli media, dan guru matematika. Setelah tahap penilaian dilakukan, maka langkah selanjutnya adalah uji coba terbatas kepada peserta didik untuk mengetahui respon peserta didik. Berikut disajikan hasil penilaian oleh ahli materi, ahli media dan guru matematika.

Tabel 2. Hasil Penilaian Kelayakan Media oleh Ahli Materi dan Guru Matematika

\begin{tabular}{llcccc}
\hline \multirow{2}{*}{ No } & $\begin{array}{l}\text { Aspek } \\
\text { penelitian }\end{array}$ & $\begin{array}{c}\text { Ahli } \\
\text { Materi 1 }\end{array}$ & $\begin{array}{c}\text { Ahli } \\
\text { Materi 2 }\end{array}$ & $\begin{array}{c}\text { Guru } \\
\text { matematika 1 }\end{array}$ & $\begin{array}{c}\text { Guru } \\
\text { matematika 2 }\end{array}$ \\
\cline { 2 - 6 } 1. & Materi & 70 & 82 & 81 & 81 \\
\hline 2. & $\begin{array}{l}\text { Fungsi dan } \\
\text { manfaat }\end{array}$ & 41 & 38 & 36 & 38 \\
\hline 3. & bahasa & 18 & 16 & 17 & 16 \\
\hline 4. & jumlah & 129 & 136 & 134 & 135 \\
\hline 5. & Rata-rata & 4,03 & 4,25 & 4,29 & 4,22 \\
\hline 6. & kategori & Layak & Layak & Layak & Layak \\
\hline
\end{tabular}

Tabel 2. Menunjukkan bahwa hasil validasi produk yang dikembangkan berdasarkan penilaian dari ahli materi dan guru matematika adalah layak. Ditinjau dari segi materi, fungsi dan manfaat, serta Bahasa dari produk yang dikembangkan memenuhi kriteria layak. Dari tabel tersebut dapat diketahui bahwa penilaian ahli materi 2 terhadap kelayakan media lebih tinggi dari ahli materi 1. Penilaian kelayakan media oleh guru matematika 2 lebih tinggi dibandingkan dengan penilaiaan oleh guru matematika 1. 
Berikut hasil penilaian kelayakan media oleh ahli media yang ditinjau dari aspek desain sampul, desain isi, dan penyajian yang disajikan pada Tabel 3 sebagai berikut.

Tabel 3. Hasil Penilaian Kelayakan Media oleh Ahli Media

\begin{tabular}{llcc}
\hline \multirow{2}{*}{ No } & \multirow{2}{*}{ Aspek penelitian } & \multicolumn{2}{c}{ Skor Validasi } \\
\cline { 3 - 4 } & & Ahli media 1 & Ahli media 2 \\
\hline 1. & Desain sampul & 34 & 34 \\
\hline 2. & Desain isi & 37 & 34 \\
\hline 3. & Penyajian media & 41 & 45 \\
\hline 4. & Jumlah & 112 & 113 \\
\hline 5. & Rata-rata & 4,03 & 4,29 \\
\hline 6. & Kategori & Layak & Layak \\
\hline
\end{tabular}

Tabel 3 di atas menunjukkan hasil penilaian kelayakan media oleh ahli media. Penilaian berdasarkan aspek desain sampul, desain isi, dan penyajian media. Dari tabel tersebut dapat diketahui hasil penilaian oleh ahli media 1 dan ahli media 2 adalah layak. Ditinjau dari aspek desain sampul memiliki nilai yang sama. Untuk aspek desain isi penilaian ahli media 1 lebih tinggi dibandingkan ahli media 2. Untuk aspek penyajian media penilaian ahli media 2 lebih tinggi dari ahli media 1 . Dari tabel tersebut dapat disimpukan bahwa penilaian produk adalah layak.

Berikut hasil angket respon peserta didik kelas V di SDN 5 Sila disajikan pada Tabel 4 sebagai berikut.

Tabel 5. Rekapitulasi Angket Respon Siswa

\begin{tabular}{cccc}
\hline Interval & Kategori & Frekuensi (f) & Presentase (\%) \\
\hline $\boldsymbol{X}>\mathbf{4 , 2 1}$ & Sangat layak & 13 & $65 \%$ \\
\hline $\mathbf{3 , 4 0}<\boldsymbol{X} \leq \mathbf{4 , 2 1}$ & Layak & 7 & $35 \%$ \\
\hline Jumlah & & 20 & $100 \%$ \\
\hline
\end{tabular}

Tabel 5 di atas menunjukkan bahwa respon peserta didik kelas VII-1 terhadap penggunaan media komik matematika dengan pendekatan etnomatematika dinilai sangat layak oleh 13 peserta didik. Respon peserta didik untuk kategori layak sebanyak 7 peserta didik.

\section{PEMBAHASAN}

Penelitian ini merupakan jenis penelitian pengembangan (Research and Development) yang bertujuan untuk menghasilkan produk media pembelajaran yang menggunakan model 4-D (define, design, develop, dan disseminate). Media pembelajaran yang dihasilkan berupa media komik matematika dengan pendekatan etnomatematika pada materi bilangan. Media komik ini dirancang untuk siswa. Pengembangan media telah melakukan serangkaian tahapan menggunakan model 4$\mathrm{D}$, mulai dari tahap pendefinisian (define), tahap perancangan (design), tahap pengembangan (develop), dan tahap penyebaran (disseminate.)

Pada tahap pendefinisian (define) terdapat beberapa hal yang dilakukan yaitu pencarian potensi masalah dan pengumpulan data (analisis kurikulum, analisis karakter peserta didik, analisis materi, dan merumuskan tujuan). Kegiatan tersebut dilakukan untuk menentukan media pembelajaran yang akan dikembangkan. 
Berdasarkan hasil analisis pengumpulan data yang telah dilakukan, maka media yang dikembangkan adalah media komik matematika dengan pendekatan etnomatematika pada materi bilangan kelas V SD.

Pada analisis kurikulum, kurikulum yang berlaku di SDN 5 Sila adalah kurikulum 2013. Oleh sebab itu, membutuhkan pengembangan media untuk mendukung pencapaian kompetensi yang sesuai dengan kurikulum 2013. Pada analisis karakteristiksiswa, dilakukan observasi proses pembelajaran matematika dikelas dan melakukan wawancara dengan guru mata pelajaran matematika. Kegiatan observasi berfokus pada kondisi kelas saat proses pembelajaran berlangsung dengan hasil bahwa peserta didik kurang antusias dalam mengikuti pembelajaran karena tidak fokus dalam membaca buku paket yang dominan berupa teks. Pemilihan media harus mempertimbangkan karakter siswa. (Nurrita, 2018)

Tahap peracangan (design), terdapat beberapa langkah yang dilakukan yaitu: 1) penyusunan perangkat penelitian berupa tes soal pre-test dan post-test angket validasi ahli dan angket respon peserta didik; 2) pemilihan media; 3) pemilihan format; dan 4) desain awal komik. Langkah pertama yang dilakukan yaitu membuat tes acuan patokan berdasarkan pada proses pendefinisian (define). Tes ini berupa pre-test dan post-test untuk mengukur peningkatan pemahaman siswa mengenai operasi bilangan bulat. Kemudian menyusun angket validasi ahli dan angket respon berdasarkan beberapa aspek yang telah dibuat. Langkah kedua adalah pemilihan media. Media yang dikembangkan adalah media komik matematika dengan pendekatan etnomatematika berbentuk buku dan menggunakan gambar kartun. Langkah ketiga adalah pemilihan format komik dimana pemilihan format komik didasarkan pada hasil penelitian mengenai pengembangan comic math dengan pendekatan etnomatematika pada materi kubus dan balok. (Nida et al., 2017)

Langkah keempat adalah membuat desain awal media komik matematika. Pada media komik matematika terdapat lima karakter tokoh yaiu Udin, Fajar, Eri, Pak Arul, dan Kak Mina. Tokoh utama media komik matematika ini adalah Udin sedangkan yang lainnya adalah tokoh pendamping. Setelah penentuan karakter tokoh, maka selanjutnya pembuatan strory board dengan membuat alur cerita terlebih dahulu. Alur cerita yang dibuat tersebut disusun dalam bentuk story board sebuah komik yaitu dengan membaginya ke dalam panel. Dalam komik ini terdapat 132 panel, setiap panel menggambarkan kejadian, suasana, dan percakapan yang terjadi. Panel tersebut saling berkesinambungan satu sama lain. Setelah cerita terbagi ke dalam panel, langkah selanjutnya pembuatan media komik matematika dengan pendekatan etnomatematika menggunakan aplikasi medibang paint. Setelah sketsa gambar dibuat dilakukan pewarnaan mengunakna aplikasi medibang paint. Setelah semua gambar selesai diwarnai, gambar dimasukkan ke dalam microsof office word 2016 untuk diberikan balon kata/balon percakapan.

Pada tahap pengembangan (develop) terdapat beberapa hal yang dilakukan yaitu penilaian media komik matematika dengan pendekatan etnomatematika oleh dosen ahli yang terdiri dari ahli materi 1 , ahli materi 2 , ahli media 1 dan ahli media 2 . Dosen ahli yang dipilih merupakan dosen yang ahli dalam aspek-aspek pada media komik matematika dengan pendekatan etnomatematika. Setelah media komik matematika dinilai oleh para ahli, langkah selanjutnnya adalah melakukan revisi I terhadap beberapa bagian yang perlu direvisi berdasar pada penilaian para ahli. 
Bagian yang direvisi adalah warna baju pada karakter tokoh komik yaitu baju udin, Fajar, Eri, dan Pak Arul.

Hasil penilaian media oleh ahli materi 1 dan ahli materi 2 adalah perbaikan pada sampul komik yaitu warna hurufnya dihitamkan. Hasil validasi media oleh ahli media 1 dan ahli media 2 yaitu perubahan warna baju pada tokoh komik. Alasannya agar peserta didik mudah mengingat tokoh-tokohnya. Hasil validasi oleh guru matematika tidak ada perubahan alur cerita sudah bagus serta tokoh-tokohnya sudah cocok.

Setelah itu media komik matematika juga divalidasi oleh praktisi (guru matematika) yang mengajar. Media komik matematika yang telah selesai direvisi kemudian digunakan untuk uji coba terbatas. Uji coba terbatas dilakukan terhadap 20 peserta didik kelas V di SDN 5 Sila untuk diminta responnya terhadap media komik matematika ini.

Berdasarkan analisis data kelayakan media komik matematika dengan pendekatan etnomatematika dinyatakan layak oleh ahli materi, ahli media, dan guru matematika. Rata-rata skor yang diperoleh dari pengisian angket kelayakan media oleh ahli materi yaitu 4,03, ahli media sebanyak 4,15 dan guru matematika sebanyak 4,19. Ketiga rata-rata skor tersebut berada di interval skor $3,40<X \leq 4,21$ sehingga masuk kategori layak. Selain itu pada uji coba skala terbatas $65 \%$ siswa menyatakan bahwa produk media termasuk dalam kategori sangat layak dan 35\% menyatakan layak. Kemudian hasil pretest yang didapatkan sebesar 1149,5 dengan rata-rata 57,5 dan hasil posttest yang didapatkan sebesar 1439 dengan rata-rata 72 . Hasil posttest lebih tinggi dari pretest, ini menunjukkan bahwa ada peningkatan hasil belajar setelah menggunakan media komik matematika dengan pendekatan etnomatematika.

Instrument yang digunakan dalam uji coba terbatas adalah angket respon peserta didik dengan menilai beberapa aspek yaitu aspek rasa senang, aspek minat, aspek keaktifan, aspek keseriusan, aspek kemudahan dan aspek ketertarikan. Pada aspek rasa senang diperoleh rata-rata sebesar 4,4 dengan kategori sangat menarik. Pada aspek minat diperoleh rata-rata sebesar 4,2 dengan kategori menarik. Pada aspek keaktifan diperoleh rata-rata 3,9 dengan kategori menarik. Pada aspek keseriusan diperoleh rata-rata 4,2 dengan kategori menari. Pada aspek kemudahan diperoleh ratarata 4,5 dengan kategori sangat menarik dan pada aspek ketertarikan diperoleh ratarata sebesar 4,3 dengan kategori sangat menarik. Dari hasil tersebut menunjukkan bahwa produk yang dikembangkan mampu menjadi sumber belajar untuk membangun pemahaman konsep siswa.

Pada saat uji coba media komik matematika kepada pengguna (siswa) diperoleh kendala yaitu cakupan materinya yang masih terbatas sehingga perlu dibantu dengan penjelasan oleh guru agar peserta didik memahami isi materi pada media komik matematika. Pengembangan komik sebagai media pembelajaran dapat dijelaskan dengan adanya strategi pembelajaran yang di dorong oleh teori pengembangan komik pembelajaran dalam bentuk bahan teks verbal dan visual sangat bergantung pada teori persepsi visual, teori membaca, dan teori belajar. Selain itu, kendala pada media komik yaitu buku mudah rusak karena termasuk media cetak yang membutuhkan perawatan khusus agar tetap terjaga. Proses pengembangan media hanya dilakukan sampai tahap uji coba dan penyebaran. Van Eymeren, (2016)

Berdasarkan hasil data penilaian ahli terhadap media komik matematika dengan pendekatan etnomatematika sebagai produk yang dikembangkan, penelitian 
ini telah menghasilkan produk yang valid dengan kualifikasi layak. Berdasarkan data hasil respon siswa sebagai pengguna dari produk yang dikembangkan, penelitian ini berhasil menghasilkan media komik matematika dengan pendekatan etnomatematika pada materi bilangan kelas V di SDN 5 Sila dapat digunakan dalam pembelajaran.

\section{KESIMPULAN}

Berdasarkan hasil penelitian dan pengembangan media komik matematika dengan pendekatan etnomatematika pada materi bilangan dapat disimpulkan bahwa media komik yang dikembangkan layak. Ditinjau dari hasil penilaian yang dilakukan oleh dua ahli materi menunjukkan rata-rata skor sebesar 4,14 dengan kategori layak. Kemudian ditinjau dari hasil penilaian oleh dua ahli media menunjukkan rata-rata skor sebesar 4,17 dengan kategori layak. Lalu ditinjau dari hasil penilaian yang dilakukan oleh dua orang guru matematika menunjukkan rata-rata skor 4,2 dengan kategori layak. Ditinjau dari respon Siswa 13 orang menyatakan media komik sangat layak dan 7 orang menyatakan media komik layak.

\section{DAFTAR PUSTAKA}

Gumanti, A. A. M., Supriadi, N., \& Suherman, S. (2018, July). Pengaruh pembelajaran dengan musik klasik terhadap kemampuan pemecahan masalah matematis Siswa. In Prosiding Seminar Nasional Matematika Dan Pendidikan Matematika (Vol. 1, No. 2, pp. 393-399).

Tarusu, D. T., Zulela, Z., \& Adiansha, A. A. (2020). Integrasi Pembentukan Nilai Karakter Kemandirian Siswa Sekolah Dasar dalam Pembelajaran Matematika di Era Industri 4.0. Jurnal Ilmiah Mandala Education, 6(2).

Adiansha, A. A., \& Khatimah, H. (2020). Pengembangan Kreativitas Dalam Pembelajaran Matematika Melalui Model Brain Based Learning Siswa Sekolah Dasar. Jurnal Pendidikan MIPA, 10(1), 45-52

Ahmat, J., \& Sukartiningsih, W. (2013). Penggunaan Media Komik untuk Meningkatkan Keterampilan Membaca Cerita di Kelas V Sekolah Dasar. Jpgsd, 1(2), 1-9. http://jurnalmahasiswa.unesa.ac.id/index.php/jurnal-penelitianpgsd/article/view/3025

Fauzi, A., Sawitri, D., \& Syahrir, S. (2020). Kesulitan Guru Pada Pembelajaran Matematika Di Sekolah Dasar. Jurnal Ilmiah Mandala Education, 6(1), 142148. https://doi.org/10.36312/jime.v6i1.1119

Lastaria, L., \& Istiqlaliyah, I. (2019). Problematika Guru Dalam Pembelajaran Matematika Pada Pendidikan Inklusi. Jurnal Hadratul Madaniyah, 6(1). https://doi.org/10.33084/jhm.v6i1.878

Nida, izza K., Buchori, A., \& Murtianto, Y. H. (2017). Pengembangan Comic Math dengan Pendekatan Etnomatematika pada Meteri Kubus dan Balok di SMP. Aksioma: Jurnal Matematika Dan Pendidikan Matematika UPGRIS Semarang, $8(1), 31-40$.

Nurrita, T. (2018). Pengembangan Media Pembelajaran untuk Meningkatkan Hasil Belajar Siswa. Misykat, 3(1). https://doi.org/10.33511/misykat.v3i1.52

Rachmat, L., \& Winata, H. (2019). Kompetensi profesional guru dan media pembelajaran powerpoint sebagai upaya untuk meningkatkan efektivitas pembelajaran. Jurnal Pendidikan Manajemen Perkantoran, 4(1), 38. 
https://doi.org/10.17509/jpm.v4i1.14953

Rudyanto, H. E. (2019). Etnomatematika Budaya Jawa : Inovasi Pembelajaran

Matematika Di Sekolah Dasar. Jurnal Bidang Pendidikan Dasar, 3(2), 25-32.

https://doi.org/10.21067/jbpd.v3i2.3348

Tusriyanto, T. (2020). Pengembangan Model Pembelajaran Terpadu Berbasis

Budaya Lokal di SD Kota Metro. Elementary: Jurnal Ilmiah Pendidikan Dasar, 6(1), 59. https://doi.org/10.32332/elementary.v6i1.2206

Van Eymeren, M. M. (2016). Memahami Persepsi Visual: Sumbangan Psikologi

Kognitif Dalam Seni Dan Desain. ULTIMART Jurnal Komunikasi Visual, 7(2), 47-63. https://doi.org/10.31937/ultimart.v7i2.387 